"The innovative activity of enterprises and national economy growth: Ukraine, Poland"

\begin{tabular}{|c|c|c|}
\hline AUTHORS & \multicolumn{2}{|l|}{$\begin{array}{l}\text { Viktoriia Tomakh } \\
\text { Hanna Veretennykova }\end{array}$} \\
\hline ARTICLE INFO & \multicolumn{2}{|c|}{$\begin{array}{l}\text { Viktoriia Tomakh and Hanna Veretennykova (2020). The innovative activity of } \\
\text { enterprises and national economy growth: Ukraine, Poland. Economics of } \\
\text { Development, 19(2), 22-32. doi:10.21511/ed.19(2).2020.03 }\end{array}$} \\
\hline DOI & \multicolumn{2}{|c|}{ http://dx.doi.org/10.21511/ed.19(2).2020.03 } \\
\hline RELEASED ON & \multicolumn{2}{|l|}{ Friday, 19 June 2020} \\
\hline RECEIVED ON & \multicolumn{2}{|l|}{ Tuesday, 17 March 2020} \\
\hline ACCEPTED ON & \multicolumn{2}{|l|}{ Thursday, 04 June 2020} \\
\hline & \multicolumn{2}{|l|}{$(\mathrm{cc}) \mathrm{EY}_{\mathrm{EY}}$} \\
\hline LICENSE & \multicolumn{2}{|c|}{$\begin{array}{l}\text { This work is licensed under a Creative Commons Attribution } 4.0 \text { International } \\
\text { License }\end{array}$} \\
\hline JOURNAL & \multicolumn{2}{|l|}{ "Economics of Development" } \\
\hline ISSN PRINT & \multicolumn{2}{|l|}{$1683-1942$} \\
\hline ISSN ONLINE & \multicolumn{2}{|l|}{$2304-6155$} \\
\hline PUBLISHER & \multicolumn{2}{|c|}{ LLC "Consulting Publishing Company "Business Perspectives" } \\
\hline FOUNDER & \multicolumn{2}{|c|}{ Simon Kuznets Kharkiv National University of Economics } \\
\hline \multirow[b]{2}{*}{ NUMBER OF REFERENCES } & & 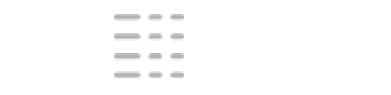 \\
\hline & NUMBER OF FIGURES & NUMBER OF TABLES \\
\hline 17 & 8 & 0 \\
\hline
\end{tabular}

(C) The author(s) 2021. This publication is an open access article. 


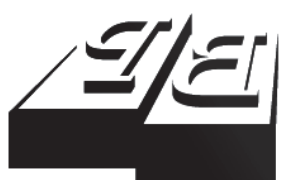

BUSINESS PERSPECTIVES

Publisher

LLC "CPC "Business Perspectives" Hryhorii Skovoroda lane, 10, Sumy, 40022, Ukraine www.businessperspectives.org

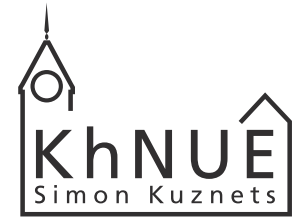

\section{S. KUZNETS KHNUE}

Founder

Simon Kuznets Kharkiv National University of Economics, Nauky avenue, 9-A, Kharkiv, 61166,

Ukraine

http://www.hneu.edu.ua/

Received on: 17th of March, 2020 Accepted on: 4th of June, 2020 Published on: 19th of June, 2020

(C) Viktoriia Tomakh,

Hanna Veretennykova, 2020

Viktoriia Tomakh, Ph.D. (Economics), Associate Professor, Simon Kuznets Kharkiv National University of Economics, Ukraine.

Hanna Veretennykova, Ph.D. (Economics), Associate Professor, Simon Kuznets Kharkiv National University of Economics, Ukraine.

\section{(c) (i)}

This is an Open Access article, distributed under the terms of the Creative Commons Attribution 4.0 International license, which permits unrestricted re-use, distribution, and reproduction in any medium, provided the original work is properly cited.

\title{
THE INNOVATIVE ACTIVITY OF ENTERPRISES AND NATIONAL ECONOMY GROWTH: UKRAINE, POLAND
}

\begin{abstract}
In the contemporary world, the sustainable development of national economies is impossible without the timely and high-quality implementation of innovation. The prompt use of innovations is considered to be the key to obtaining and maintaining both new and existing competitive advantages of both individual enterprises and the economy in general. This study aims to determine the dependence of national economic growth (based on the example of Ukraine and Poland) on the innovative activities of enterprises and innovative policies of governments, as well as the development of the improvement offers concerning the innovative policy of Ukraine based on international experience. The impact of innovation indicators on the level of GDP per capita in Ukraine and Poland over the period from 2000 to 2018 has been studied in the article. The most important factors of influence on the GDP per capita, through multivariate statistical analysis and regression analysis, were identified from the list of indicators of innovation activity, and the regression equation was constructed. For Ukraine, such factors are the "innovativeness of enterprises" (that explains the $34.19 \%$ of total dispersion), the "innovative inputs" (that explains the $17.11 \%$ of dispersion) factors and factor of "financing and implementation of innovations" (that explains $27.8 \%$ of the total dispersion). For Poland, the factor of "innovative activity" explains $44.35 \%$ of dispersion, and the factor of "innovative actions" explains $38.47 \%$ of total dispersion. Moreover, the suggestions involving innovation policy development of Ukraine are provided.
\end{abstract}

Keywords

JEL Classification

В. В. Томах (Україна), Г. Б. Веретенникова (Україна) innovation, innovative activity, national economy, GDP, competitiveness, growth

$\mathrm{O} 31, \mathrm{O} 33, \mathrm{O} 47$

\section{ІННОВАЦІЙНА ДЯЛЬНІСТЬ ПІДПРИЄМСТВ ТА ЗРОСТАННЯ НАЦІОНАЛЬНОЇ ЕКОНОМІКИ: УКРАЇНА, ПОЛЬЩА}

\section{Анотація}

В сучасних умовах стійкий розвиток жодної з національних економік не можливий без своєчасного та якісного впровадження інноваційної діяльності. Саме своєчасне використання інновацій $є$ запорукою отримання нових та збереження вже існуючих конкурентних переваг як окремих підприємств, так і економіки в цілому. Метою даного дослідження $є$ визначення залежності зростання національної економіки (на прикладі України та Польщі) від інноваційної діяльності підприємств та інноваційної політики держави, а також розроблення пропозицій щодо удосконалення інноваційної політики України спираючись на світовий досвід.

В статті було досліджено вплив показників інноваційної діяльності на рівень ВВП на душу населення в Україні та Польщі за період з 2000 по 2018 рр. За допомогою багатовимірного статистичного аналізу, а саме методу головних компонент, та регресійного аналізу з переліку показників інноваційної діяльності було виділено найбільш важливі фактори впливу на ВВП на душу населення та побудовано рівняння регресії. Для України такими факторами є фактор «інноваційності підприємств», що пояснює 34.19\% загальної дисперсії, фактор «інноваційних входів» пояснює 17.11\% дисперсії та фактор «фінансування та впровадження інновацій» пояснює 27.8\% загальної диперсії. Для Польщі це фактор «інноваційної активності», що пояснює 44.35\% дисперсії та фактор «інноваційний вихід», він пояснює 38.47\% загальної дисперсії. Надано рекомендації для вдосконалення інноваційної політики України.

\section{Ключові слова}

Класифікація JEL інновації, інноваційна діяльність підприємств, національна економіка, ВВП, конкурентоспроможність, зростання

O31, O33, O47 


\section{ВСТУП}

Конкурентоспроможність та ріст економіки держав залежить від значної кількості чинників, серед яких особливе місце займають чинники, що пов'язані 3 інноваційною діяльністю. Саме своєчасне та якісне реагування на зміни в зовнішньому середовищі, вміння визначати пріоритети розвитку

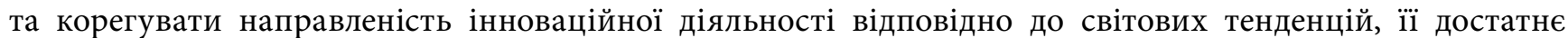
та постійне фінансування є однією з запорук як зростання економіки держави, так і утримання конкурентоспроможності на світовому ринку. Інноваційна активність, розвиток науки, розмір фінансування науково-дослідних та дослідно-конструкторських робіт (НДДКР), розвиток техніки і технології, рівень освіти, кількість отриманих патентів тощо - всі ці показники відображають результати інноваційної діяльності підприємств та результати інноваційної політики держави та $\epsilon$ основою для забезпечення прогресу та конкурентоспроможності національної економіки, стійкого економічного зростання та розвитку, покращення рівня та якості життя населення. Водночас, в Україні в 2018 р. за даними державного комітету статистики України лише 16\% підприємств були інноваційно активними, а витрати на інновації склали $0.34 \%$ від ВВП, що значно нижче розміру витрат необхідного для впровадження інноваційної моделі розвитку економіки [15].

Впровадження та результати інноваційної діяльності підприємства не можна розглядати окремо від інноваційної політики держави, бо саме вона створює та регулює умови, що сприяють та роблять можливою інноваційну діяльність підприємств. В свою чергу, якісна інноваційна діяльність сприяє зростанню національної економіки, що знаходить своє відображення в зростанні таких показників, як: валовий внутрішній продукт на душу населення, виробництво і споживання основних видів продукції на душу населення, показники ефективності економіки (які обчислюються на основі ВВП), національний дохід на душу населення та рівень та якість життя населення, що й обумовлює актуальність даного дослідження.

\section{1. ЛІТЕРАТУРНИЙ ОГЛЯА}

Дослідженням взаємозв'язків між результатами інноваційної політики держави, інноваційної діяльності підприємства та зростанням рівня національної економіки займалися такі зарубіжні та вітчизняні вчені, як Арчібугі, Андріа, Водянка, Іванілов, Кіек, Краус, Матрас-Болібок, Олівера, Орос, Підгірна, Філіппетті, Флоріна, Френц та інші.

Так, Андріа, Олівера та Флоріна в своєму дослідженні [14] доводять, що саме інновації, витрати та НДДКР та інвестиції в технології $€$ основою для забезпечення конкурентоспроможності держави та стійкого економічного зростання. На прикладі ряду країн, а саме Угорщини, Чешської республіки та Польщі за допомогою моделей множинної регресії вони аналізують залежність довгострокового економічного зростання від інноваційного потенціалу економіки. В результаті якого вони доводять, що на економічне зростання впливають такі чинники, як інновації (кількість патентів, рівень витрат на дослідження та розробки), обсяг прямих іноземних інвестицій, освіта та експорт.

Водночас, Арчібугі, Філіппетті та Френц в своєму дослідженні [3] стверджують та доводять про відсутність прямої залежності між інноваційною діяльністю та економічним станом в державі. Вони провели аналіз підприємств 27 держав-членів $Є С$, а також Норвегії та Швейцарії. Отримані результати доводять, що незважаючи на те, що економічна криза змушує ряд підприємств знизити свої інвестиції в інновації, але це зниження не $є$ однаковим для всіх підприємств, бо деякі з них навпаки збільшують витрати на інвестиції в інновації.

Відносно переваги на світовому ринку країн, в економічному розвитку яких переважає інноваційна діяльність говорять в своїй роботі й Водянка та Підгірна [17]. Вони доводять, що держави здобувають гідного рівня національної економіки саме через впровадження інновацій та проведення якісної інноваційної політики, що полягає не тільки в прямому державному фінансуванні, а й в залученні методів стимулювання до розроблення та впровадження інновацій. Така інноваційна політика притаманна таким країнам, як Франція, Німеччина, США, Японія та ряд інших, що зазвичай займають перші сходинки, як за рівнем національної економіки, так і за рівнем якості життя населення. 
Кійєк та Матрас-Болібок розглядають взаємозалежність між інноваційною діяльністю та таким показником національної економіки як TFP (загальна продуктивність чинників) [7]. Вони роблять наголос, що на результати інноваційної діяльності підприємств і як наслідок на рівень зростання економіки впливають й території на яких вони знаходяться, бо саме зростання економіки та географічна агломерація господарської діяльності $є$ взаємозалежними процесами, що й пояснює чому при однакових вхідних даних, що забезпечують інноваційну діяльність на виході на різних територіях мають різні значення. Й найбільші та якісніші результати інноваційної діяльності підприємств будуть в тих регіонах, в яких подібна діяльність вже впроваджувалась, що пов’язано з кумулятивністю знань.

Зв’язок між темпами економічного зростання (показник ВВП надушу населення) та компонентами інтелектуального капіталу (результат інноваційної діяльності) досліджують в своїй роботі й Кузькін, Черкашина та Небаба [10]. Вони дослідили дві групи постсоціалістичних країн Центральної та Східної Європи. Виявлено, що для держав з середнім рівнем доходу зростання національної економіки є залежним від комерціалізації нових знань, технологій та впровадження сучасних інформаційних технологій. Водночас, для держав з рівнем доходу нижче середнього ключовим чинником зростання економіки $\epsilon$ людський капітал, а саме рівень освіти, кількість вчителів, відсоток людей з вищою освітою.

Впровадження інновацій здійснює вплив не тільки на конкурентоспроможність окремих підприємств, а й на національну економіку в цілому, тобто її інноваційну глокалізацію, тобто є одним з головних ресурсів економічного росту [9, с. 38$]$.

Вплив на конкурентоспроможність національних економік інноваційного потенціалу в державах членах $\in C$, а саме Австрії та Німеччини досліджують Ломачинська та Підгірна [12]. В якості залежних змінних виступили показники ВВП та частка експорту товарів та послуг в ВВП. Незалежними показниками, що відображають інноваційну діяльність було обрано наступні: частка дослідників в НДДКР від загальної чисельності населення, частка працездатного населення з вищою освітою до загальної чисельності працездатного населення, витрати на вищу освіту в відсотках від ВВП, витрати на НДДКР в відсотках від ВВП та відсоток патентних заявок від загальної чисельності населення. В результаті аналізу було визначено, що найбільший вплив на конкурентоспроможність національних економік Австрії та Німеччини здійснив показник частка дослідників НДДКР в загальній кількості населення. Водночас інші впливові показники різнились. Так, для Німеччини це показник витрат на вищу освіту в відсотках до ВВП, а для Австрії показники: витрати на НДДКР в відсотках від ВВП та кількість патентних заявок в відсотках до загальної чисельності населення. Значний вплив на конкурентоспроможність держави якісного рівня населення доводить й Ахмадов [1].

В сучасних умовах на світових ринках лідерами можуть бути та є тільки ті держави, в економічному розвитку яких інноваційна діяльність займає провідне місце $[6,11]$. Інновації $є$ головним джерелом конкурентоспроможності підприємств як на внутрішньому, так і на світовому ринку та ключовим елементом підвищення продуктивності та зростання економіки [2].

Так, аналіз вищерозглянутих досліджень дозволяє зробити висновок про наявність взаємозв'язка між інноваційною діяльністю підприємства та зростанням рівня національних економік. Водночас, в різних країнах даний зв'язок прослідковується між різними показниками, що відображають дані процеси. Завданням даного дослідження є визначення взаємозв'язків між інноваційною діяльністю підприємств та рівнем національних економік України та Польщі.

\section{2. МЕТА ДОСЛІДЖЕННЯ}

Метою даного дослідження є визначення залежності зростання національної економіки (на прикладі України та Польщі) від інноваційної діяльності підприємств та інноваційної політики держави, а також розроблення пропозицій щодо удосконалення інноваційної політики України спираючись на світовий досвід. 


\section{3. РЕЗУЛЬТАТИ ДОСЛІДЖЕННЯ}

На даний час існує декілька міжнародних систем оцінки, що відображають рівень інноваційності держав. Одним із таких показників $є$ Глобальний інноваційний індекс. Глобальний інноваційний індекс враховує 80 параметрів які дозволяють максимально врахувати всі аспекти, що впливають та відображають стан інноваційності в державі. В 2019 році за даним індексом було оцінено 129 держав, перше місце серед яких зайняла Швейцарія (очолює даний індекс більше 5 років) з показником 67.24 за 100 бальною шкалою, водночас Україна посіла 47 місце з показником 37.4 спустившись в порівнянні з 2018 р. на 4 місця (43 місце з показником 38.5) [5]. На Рисунку 1 представлено результати оцінки національної економіки України та ряду держав, що зайняли суміжні місця за глобальним інноваційним індексом в 2019 р. В Україні найгірше положення з таких компонент глобального інноваційного індексу, як: інститути та інфраструктура, тобто саме з тих компонент, що забезпечують умови інноваційної діяльності. Водночас за групою компоненти розвиток технологій та економіка знань Україна серед досліджуваних держав займає найкращу позицію.

Оцінювання інноваційного розвитку держав-членів ЄС та ще декількох держав проводить за допомогою Європейського табло інновацій, яке враховує 10 груп показників, що відображають розвиток держав відносно інноваційного рівня. Серед держав, що не входять в склад $€ С$, але оцінка інноваційного рівня яких проводиться за допомогою даного індикатора $є$ й Україна. На Рисунку 2 результати оцінки інноваційного розвитку України та ряду держав за Європейським табло інновацій. Найгірший стан відмічається в групах показників: зв’язки, фінанси та підтримка, інноваційна середа. Отримані оцінки
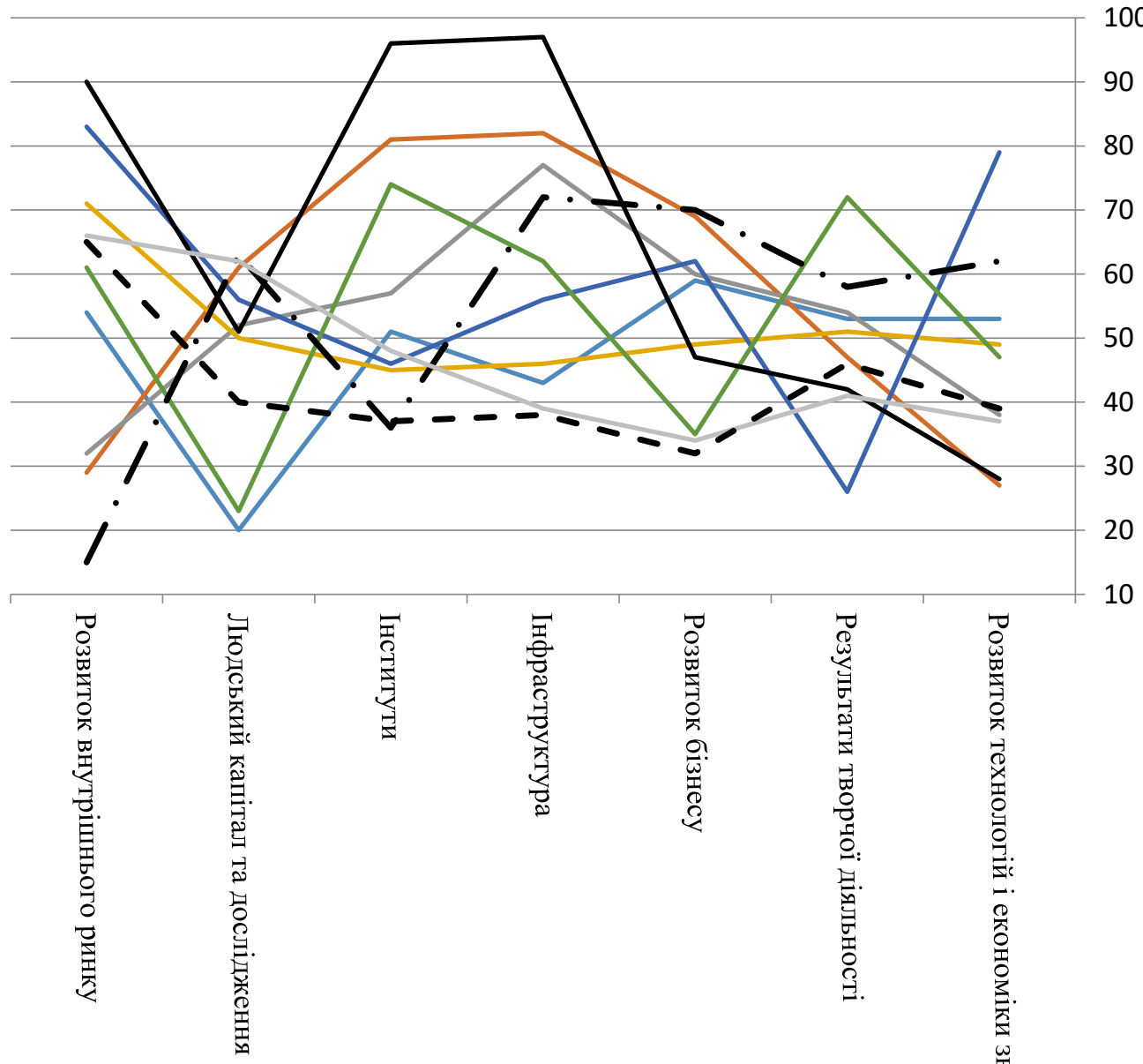

Російська федерація (46) - • Грузія (48)

— Україна (47) Болгарія (40)

- - Польща (39)

Рисунок 1. Глобальний інноваційний індекс в 2019 р. 
майже співпадають з результатами оцінки за глобальним інноваційним індексом, що підтверджує необхідність особливої уваги до покращення стану саме фінансування інноваційної діяльності, створення благо сприятливої інноваційної інфраструктури України та покращення взаємозв’язків.

Важливим показником інноваційного розвитку держави, що враховано в обох розглянутих методиках оцінки інноваційності є витрати на НДДКР в відсотках від ВВП, аналіз даного показника за 2002-2017 pp. наведено на Рисунку 3. В середньому в світі доля витрат на НДДКР від ВВП складають близько $2 \%$ та в 2017 р. даний показник склав 2.22\%. За період з 2000 по 2017 рр. в Греції доля таких витрат збільшилась в два рази: $30.56 \%$ в 2000 р. до $1.13 \%$ в 2017 році. В Болгарії та Польщі заданий період також відбулась суттєва зміна в розмірі даного показника, а саме з $0.5 \%$ та $0.64 \%$ в 2000 р. до $0.75 \%$ та $1.03 \%$ в 2017 р. відповідно. Водночас в Україні за даний період часу доля витрат на НДДКР зменшилась майже в 2 рази, 3 0.96\% в 2000 р. до $0.45 \%$ в 2017 р., що суперечить світовим тенденціям інноваційного розвитку.

Для подальшого аналізу було обрано Україну та Польщу. Вибір Польщі обумовлено тим, що дана країна за більшістю показників інноваційної діяльності йде попереду України (в попередній десятці), тобто може бути прикладом для наслідування та водночас, в порівнянні з іншими країнами, що також знаходяться в попередній десятці $€$ країною, що найбільш схожа за історично-географічними та соціальноекономічними умовами, а також за менталітетом населення.

Одним із основних показників рівня національних економік $є$ ВВП. Але це далеко не єдиний показник, що характеризує рівень як національних економік взагалі, так і рівень конкурентоспроможності держави. В світовій практиці та науковій літературі $\epsilon$ ціла низка показників, що використовується з метою оцінки конкурентоспроможності, інноваційності економіки держави та їі розвитку. Водночас, показники, що характеризують рівень розвитку національних економік є залежними від ефективної діяльності підприємств.

Так, величина валового внутрішнього продукту в 2018 році склала $3,560,596.0$ млн грн, що в 20 разів більше ніж в 2000 р. Водночас, якщо абсолютне значення фінансування інноваційної діяльності промислових підприємств в 2018 р. склало 12,180.10 млн грн, що більше даного показника в 2000 р. лише в 6 разів, його

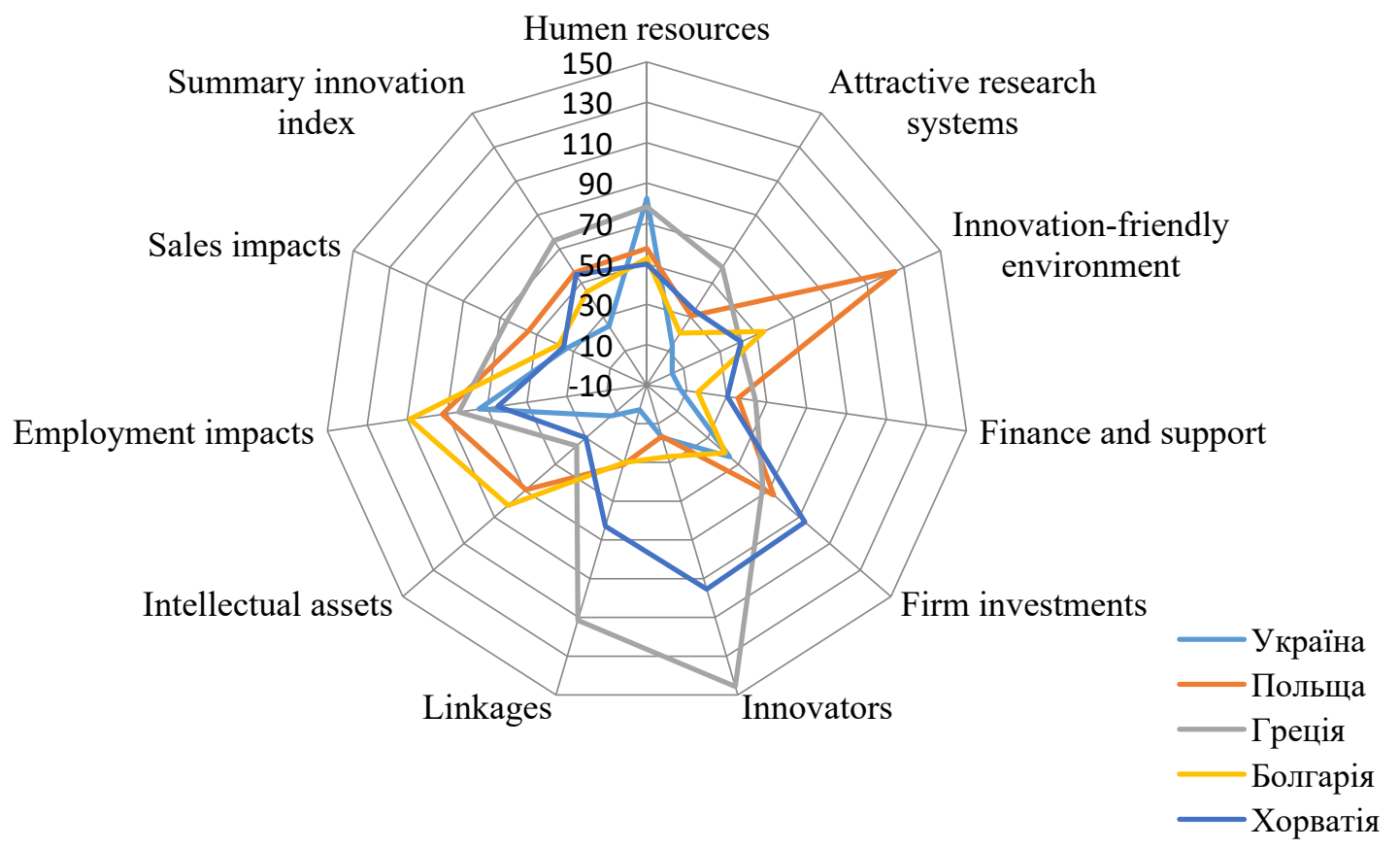

Рисунок 2. Рівень інноваційного розвитку держав за Європейським інноваційним таблом, 2018 р. 


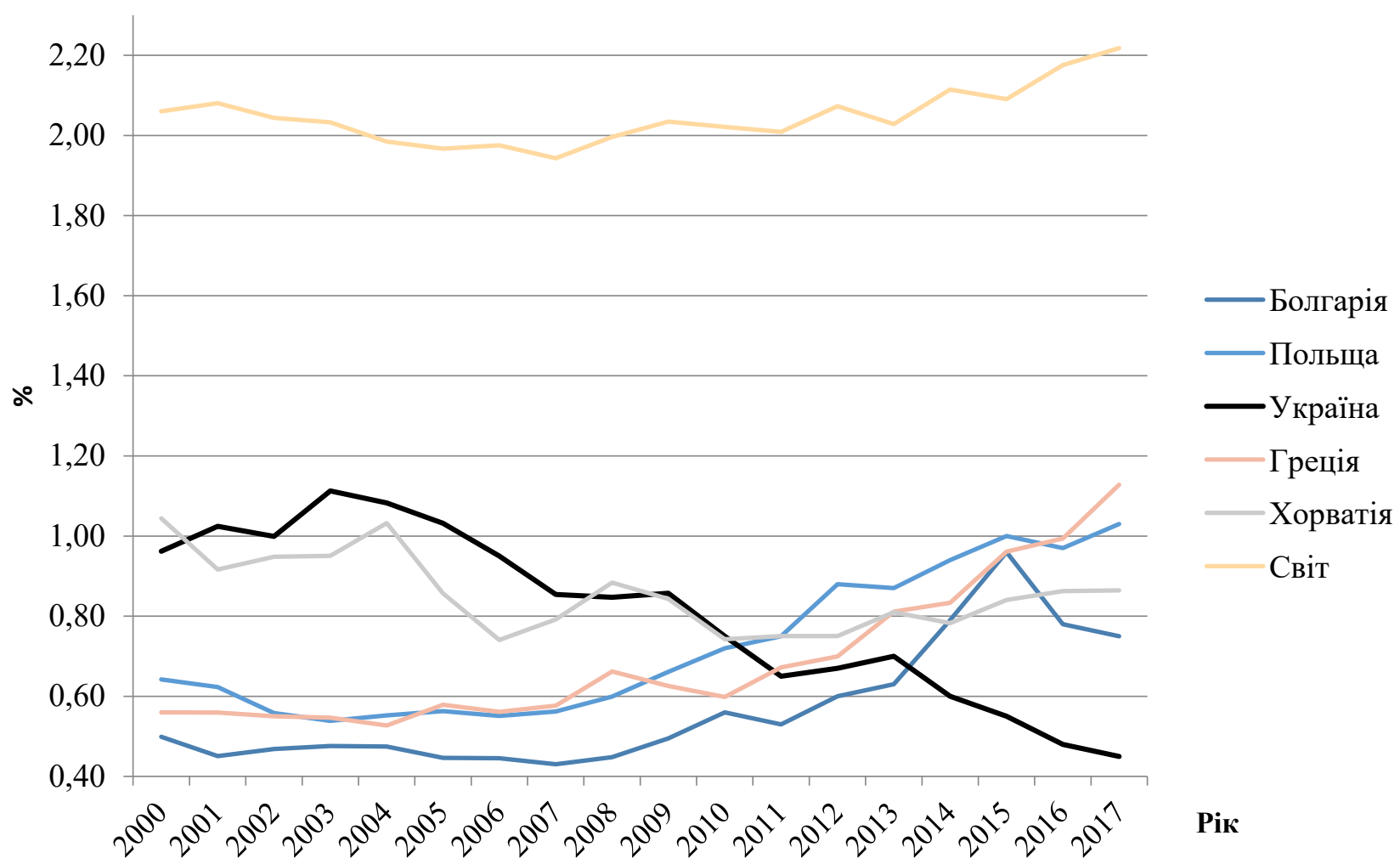

Рисунок 3. Витрати на НДДКР в відсотках до ВВП

розмір відносно ВВП скоротився з 1\% в 2000 р. до $0.34 \%$ в 2018 р. Також суттєве зменшення торкнулося й таких показників, як: кількість промислових підприємств, що впроваджували інновації (майже в 2 рази), кількість упроваджених видів інноваційної продукції (майже в 4 рази), відсоток реалізованої інноваційної продукції до загального обсягу реалізованої промислової продукції (більш ніж в 11 разів), кількість виданих патентів (майже в 2 рази), що є результатом погіршення стану умов для інноваційної діяльності підприємств.

Для визначення впливу показників інноваційної діяльності підприємств на рівень національної економіки були проаналізовані дані за період з 2000 по 2018 рр. по Україні та Польщі. Базою дослідження стали дані представлені в офіційних джерелах інформації $[5,8,13,15,16]$. В якості залежної змінної було обрано показник ВВП на душу населення $(Y)$. До незалежних змін було віднесено наступні показники інноваційної діяльності: кількість інноваційно активних промислових підприємств (X1), витрати на інновації (X2), кількість промислових підприємств, що впроваджували інновації $(X 3)$, кількість упроваджених у виробництво нових технологічних процесів $(X 4)$, кількість упроваджених видів інноваційної продукції (X5), обсяг реалізованої інноваційної продукції (X6), та кількість виданих патентів (X7).

Дослідження було проведено за допомогою багатовимірного статистичного аналізу, а саме методом головних компонент. Вибір даного методу пов'язано з необхідністю визначення структури взаємозалежності між показниками та стиснення інформації, тобто зменшення кількості незалежних показників на основі виявлення стохастичного зв’язку між ними, виділенні найбільш важливих факторів, що впливають на той чи інший результат, а також підтвердити значимість впливу цих факторів. Всі вхідні дані у матриці $A$ представлені без пропусків. Результуючим вектором є ВВП $(Y)$. Відображення $F$ співставляє з кожним рядком аіТ матриці $A$ інтегральний вектор $Y i$ та побудовано методом головних компонент: $F: A \rightarrow Y$. Перетворення обертання відповідає критерію найбільшої інформативності Рао (відповідно до цього критерію найбільша інформативність $є$ мінімальним значенням суми квадратів відстаней від зображень об’єктів до їх проекцій на першу головну компоненту). Всі розрахунки виконано з використанням програмного пакету STATISTICA. 
Аналіз даних інноваційної діяльності підприємств (незалежних показників) по Україні дозволив виявити три фактори (Рисунок 4).

Застосування методу головних компонент дозволило виявити, що перша головна компонента обумовлює $34.19 \%$ дисперсії, друга головна компонента обумовлює $17.11 \%$ і третя компонента $27.8 \%$ тобто дані фактори пояснюють більше 70\% дисперсії.

Таким чином, методом головних компонент було виявлено три основні фактори впливу на розмір ВВП України. При аналізі інтенсивності факторного навантаження було визначено наявність усіх трьох ступенів впливу, а саме: до 0.5 - слабкий вплив, від 0.5 до 0.7 - середній, більш 0.7 - наявність сильного впливу. Для подальшого аналізу доцільно обрати показники, значення яких у більшому ступені відображають вплив інноваційної діяльності, використовуючи значення факторних навантажень, що близькі до 0.60 і вище.

Дані фактори можна ідентифікувати наступним чином: 1 фактор - «інноваційності підприємств», 2 фактор - «інноваційних виходів» та 3 фактор «фінансування та впровадження інновацій». Так, при аналізі першого фактора «інноваційності підприємств», було виявлено, що найбільш високе значення має навантаження наступних показників: кількість промислових підприємств, що впроваджували інновації (X3) та кількість інноваційно активних промислових підприємств (X1). До другого фактору «інноваційних виходів» увійшов один показник: обсяг реалізованої інноваційної продукції (Х6). Та два показники увійшли до третього фактора «фінансування та впровадження інновацій», а саме: витрати на інновації (X2) та кількість упроваджених у виробництво нових технологічних процесів $(X 4)$. Статистична значимість підтверджена рівнем $p$-рівень, що дорівнює 0.004.

Виділення трьох факторів було підтверджено й графічним визначенням оптимального число факторів за допомогою графіка кам’янистого осипу, Рисунок 5.

Таким чином, незалежні показники, що не увійшли до жодного з факторів 3 подальшого дослідження було виключено, а саме показники: кількість упроваджених видів інноваційної продукції (X5) та кількість виданих патентів (X7).

Узагальнюючи отримані результати, можна зробити висновок, що найбільший вплив на рівень інноваційноїдіяльності за період, що аналізувався, а саме з 2000-2018 залежав від фактора «інноваційності підприємств».

\begin{tabular}{||l|r|r|r|}
\hline \multirow{4}{*}{ Variable } & \multicolumn{3}{|l}{$\begin{array}{l}\text { Factor Loadings (Varimax raw) (Spreadsheet3) } \\
\text { Extraction: Principal components } \\
\text { (Marked loadings are }>, 700000)\end{array}$} \\
\cline { 2 - 4 } & \multicolumn{1}{|c|}{ Factor } & \multicolumn{1}{|c}{ Factor } & \multicolumn{1}{|c}{ Factor } \\
\hline X1 & $-0,940665$ & $-0,049771$ & \multicolumn{1}{c}{3} \\
\hline X2 & 0,339549 & 0,069271 & $-0,871727$ \\
\hline X3 & $-0,954947$ & 0,076723 & 0,171372 \\
\hline X4 & 0,060158 & $-0,007277$ & $-0,928167$ \\
\hline X5 & $-0,535137$ & 0,397328 & 0,477807 \\
\hline X6 & 0,068812 & $-0,889986$ & 0,015064 \\
\hline X7 & $-0,432501$ & $-0,484480$ & 0,201117 \\
\hline Expl.Var & 2,393852 & 1,197881 & 1,946172 \\
\hline Prp.Totl & 0,341979 & 0,171126 & 0,278025 \\
\hline
\end{tabular}

Джерело: Розраховано автором.

Рисунок 4. Результати аналізу показників інноваційної діяльності підприємств України за 2000-2018 рр. методом головних компонент 


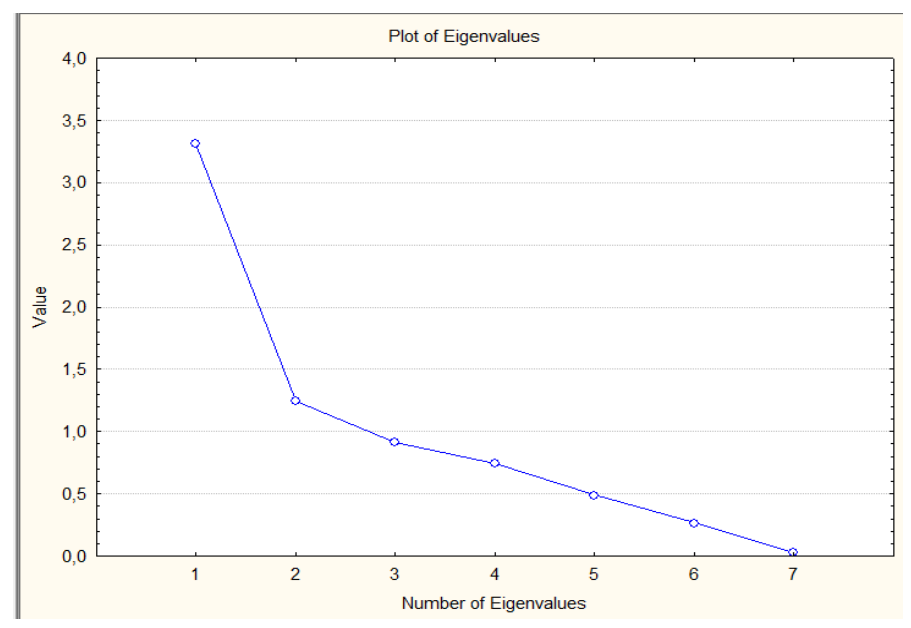

Рисунок 5. Графік кам'янистій осипи

У зв’язку з тим, що однією з цілей впровадження та розвитку інноваційної діяльності є зростання конкурентоспроможності та рівня національної економіки, а одним із показників, що ії характеризує $\epsilon$ показник ВВП на душу населення даний показник було обрано як залежну змінну (регресанд), показники ж інноваційної діяльності було визначено як незалежні, що пояснюють змінні (регресори).

3 метою виявлення та вивчення зв’язку залежної змінної від декількох незалежних, було використано регресійний аналіз, за допомогою якого стає можливою розробка економіко-математичної моделі впливу показників інноваційної діяльності на рівень ВВП на душу населення України. Побудова багатофакторної регресійної моделі дозволяє кількісно відобразити вплив показників інноваційної діяльності на рівень ВВП на душу населення України. У процесі проведення регресійного аналізу були виключені фактори $X 1, X 3$ та $X 6$ як такі, вплив яких на регресант $€$ не значущим. Остаточні результати регресійного аналізу представлено на Рисунку 6 та було отримано наступне рівняння регресії:

$Y=687.152+2.29 \cdot X 2+1.1 \cdot X 4$.

Значення коефіцієнта детермінації для періоду, що аналізується дорівнює 0.9624. Це свідчить про те, що побудована регресія пояснює 96.24\% дисперсії ВВП на душу населення. Статистичну значущість отриманих результатів було перевірено за $F$-статистикою. Оскільки отримане значення більше $F$ таблиці, нульова гіпотеза відхиляється, тобто коефіцієнти регресії є значущими й достатньо пояснюють залежну змінну. Входження показників у регресійну модель перевірено за допомогою $t$-критерія Стьюдента з 95\% рівнем довіри.

Таким чином, показниками, що мають найбільший вплив на розмір ВВП на душу населення України $\epsilon$ показники: витрати на інновації (X2) та кількість упроваджених у виробництво нових технологічних

\begin{tabular}{|c|c|c|c|c|c|c|}
\hline \multirow[b]{2}{*}{$N=19$} & \multicolumn{6}{|c|}{$\begin{array}{l}\text { Regression Summary for Dependent Variable: } Y \text { (Spreadsheet1) } \\
R=, 98102382 \mathrm{R} ?=, 96240774 \text { Adjusted R? }=, 95770870 \\
F(2,16)=204,81 p<, 00000 \text { Std. Error of estimate: } 4752,0\end{array}$} \\
\hline & Beta & $\begin{array}{l}\text { Std.Err. } \\
\text { of Beta }\end{array}$ & B & $\begin{array}{c}\text { Std. Err. } \\
\text { of B }\end{array}$ & $t(16)$ & p-level \\
\hline Intercept & & & 687,152 & 379,488 & 0,18107 & 0,008586 \\
\hline X2 & 0,993666 & 0,055689 & 2,290 & 0,128 & 17,84318 & 0,055155 \\
\hline X4 & 0,621771 & 0,055689 & 1,103 & 2,342 & 0.47079 & 0,006441 \\
\hline
\end{tabular}

Рисунок 6. Результати регресійного аналізу 
процесів (X4). Тобто, збільшуючи саме витрати на інновації, що на даний час є значно меншими за світові норми, та впроваджуючи у виробництво нові технологічні процеси, ми маємо можливість підвищити рівень ВВП на душу населення й таким чином покращити, як рівень національної економіки України, так і якість життя населення держави.

Аналіз впливу показників інноваційної діяльності підприємств Польщі на ВВП держави за допомогою методу головних компонент (Рисунок 6) дозволив виділити два фактори, що пояснюють $82.8 \%$ загальної дисперсії. До першого фактора увійшли показники: кількість інноваційно активних промислових підприємств (X1), кількість промислових підприємств, що впроваджували інновації (X3) та кількість упроваджених у виробництво нових технологічних процесів (X4). Даний фактор (перша головна компонента) доцільно інтерпретувати, як фактор інноваційної активності, він пояснює $44.3 \%$ дисперсії. До другого фактора увійшли показники: кількість упроваджених видів інноваційної продукції (X5), обсяг реалізованої інноваційної продукції $(X 6)$, кількість виданих патентів $(X 7)$, що дозволяє його інтерпретувати, як фактор інноваційний вихід, він пояснює $38.4 \%$ загальної дисперсії. Таким чином, два визначені фактори впливу інноваційної діяльності підприємств Польщі на показник ВВП пояснюють більше 70\% загальної дисперсії.

3 подальшого дослідження впливу показників інноваційної діяльності на рівень ВВП на душу населення Польщі були виключено показник: витрати на інновації (X2), як такий, що не увійшов до виділених факторів.

Наступним етапом дослідження було визначення впливу кожного з незалежних показників на показник ВВП на душу населення Польщі $(Y)$. Подальший аналіз проводився за допомогою регресійного аналізу, в процесі якого було виключено фактори $X 3$ та $X 6$, як такі, що не впливають на показник ВВП на душу населення Польщі. Остаточні результати за якими побудовано регресійну модель наведено на Рисунку 8.

$Y=819.98+0.17 \cdot X 1+0.34 \cdot X 4+0.28 \cdot X 5+3.86 \cdot X 7$.

Як видно, за результатами регресійного аналізу показниками інноваційної діяльності, що здійснюють найбільший вплив на значення ВВП на душу населення в Польщі $€$ показники: кількість виданих патентів, кількість упроваджених у виробництво нових технологічних процесів, кількість упроваджених видів інноваційної продукції та кількість інноваційно активних промислових підприємств.

Таким чином, аналіз впливу показників інноваційної діяльності на ВВП на душу населення України та Польщі виявив досить суттєві розбіжності між залежністю ВВП на душу населення даних країн від

\begin{tabular}{||l|r|r|}
\hline \multirow{2}{*}{} & \multicolumn{2}{|c}{$\begin{array}{l}\text { Factor Loadings (Varima } \\
\text { Extraction: Principal cor } \\
\text { (Marked loadings are >; }\end{array}$} \\
\cline { 2 - 3 } Variable & $\begin{array}{c}\text { Factor } \\
\mathbf{1}\end{array}$ & \multicolumn{1}{c}{ Factor } \\
\hline X1 & 0,984829 & $-0,084686$ \\
\hline X2 & 0,209974 & $-0,691878$ \\
\hline X3 & 0,974038 & 0,124229 \\
\hline X4 & 0,984829 & $-0,084686$ \\
\hline X5 & 0,241884 & 0,880646 \\
\hline X6 & 0,066788 & 0,839608 \\
\hline X7 & $-0,330112$ & 0,839077 \\
\hline Expl.Var & 3,104557 & 2,693001 \\
\hline Prp.Totl & 0,443508 & 0,384714 \\
\hline
\end{tabular}

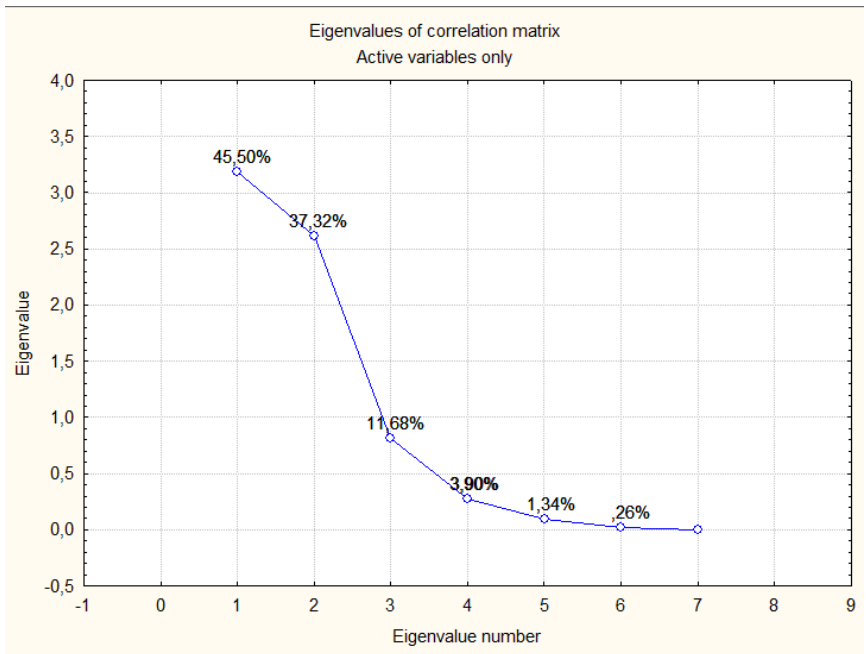

Джерело: Розраховано автором

Рисунок 7. Результати аналізу показників інноваційної діяльності підприємств методом головних компонент 


\begin{tabular}{|c|c|c|c|c|c|c|}
\hline \multirow[b]{2}{*}{$\mathrm{N}=19$} & \multicolumn{6}{|c|}{$\begin{array}{l}\text { Regression Summary for Dependent Variable: } Y \text { (Spreadsheet6) } \\
R=, 99247882 \mathrm{R} ?=, 98501421 \text { Adjusted R?= } 98073255 \\
\mathrm{~F}(4,14)=230,05 \mathrm{p}<, 00000 \text { Std. Error of estimate: } 548,81\end{array}$} \\
\hline & Beta & $\begin{array}{l}\text { Std.Err. } \\
\text { of Beta }\end{array}$ & $\mathrm{B}$ & $\begin{array}{c}\text { Std.Err. } \\
\text { of B }\end{array}$ & $t(14)$ & p-level \\
\hline Intercept & & & 819,98 & 254,797 & 3,21998 & 0,006170 \\
\hline $\mathrm{X} 1$ & 0,159603 & 0,059867 & 0,17 & 63,508 & 2,66598 & 0,018444 \\
\hline $\mathrm{X} 4$ & 0,185029 & 0,045218 & 0,34 & 82,783 & 4,09197 & 0,001099 \\
\hline$\times 5$ & 0,178358 & 0,064002 & 0,28 & 10,256 & 2,78675 & 0,014555 \\
\hline $\mathrm{X} 7$ & 0,795209 & 0,054863 & 3,86 & 7,166 & 14,49436 & 0,000000 \\
\hline
\end{tabular}

Джерело: Розраховано автором.

Рисунок 8. Результати регресійного аналізу (Польща)

досліджуваних показників. Показником що впливає на значення ВВП на душу населення як в Україні, так і в Польщі $є$ тільки показник кількості упроваджених у виробництво нових технологічних процесів, водночас вплив інших показників суттєво різниться. Зауважимо, що при аналізі впливу показників інноваційної діяльності було встановлено, що показник кількість інноваційно активних промислових підприємств здійснює негативний вплив значення ВВП на душу населення, що в свою чергу суперечить тенденціям світового інноваційного розвитку. Даний стан можна пояснити як недоліками методики збору статистичної інформації, щодо інноваційної діяльності, так і недоліками формування та впровадження інноваційної політики держави.

Для покращення інноваційної діяльності підприємств та коректування їх впливу на значення ВВП доцільно вдосконалити інноваційну політику України в декількох напрямках, а саме:

- створення цільових державно-приватних венчурних фондів та забезпечення прозорості їх функціонування;

- стимулювання кооперації наукових інститутів із підприємствами з метою прискорення трансферу технологій;

- удосконалення механізмів трансферу технологій;

- розроблення механізмів поширення вітчизняних інновацій на світові ринки;

- податкове стимулювання НДДКР;

- розроблення механізму підтримки платіжного попиту на НДДКР;

- удосконалення системи інформаційних комунікацій щодо доведення до інноваційно активних підприємств інформації щодо можливих фінансових пільг у зв'язку з їх діяльністю;

- стимулювання оновлення морально застарілого обладнання та впровадження нових неопробованих технологій.

\section{ВИСНОВКИ}

Отже, зростання національної економіки неможливо без якісного та своєчасного впровадження інноваційної діяльності на всіх рівнях. На зростання величини ВВП на душу населення впливає значний ряд чинників інноваційної діяльності перелік яких дещо може відрізнятись залежно від особливостей розвитку тієї чи іншої країни. Так, за допомогою методу головних компонент показники інноваційної діяльності України та Польщі було розподілено в декілька факторів. Для України це: 1 фактор «інноваційності підприємств», що пояснює 34.19 загальної дисперсії й до якого увійшли показники: кількість промислових підприємств, що впроваджували інновації та кількість інноваційно активних промислових підприємств, 2 фактор «інноваційних виходів», пояснює 17.11\% дисперсії та включає в себе лише один показник обсяг реалізованої інноваційної продукції та 3 фактор «фінансування та впровадження інновацій», що пояснює $27.8 \%$ загальної дисперсії. Для Польщі це фактор «інноваційної активності», що пояснює 44.35\% дисперсії та включає в себе наступні показники: кількість інноваційно активних промислових підприємств, кількість промислових підприємств, що впроваджували інновації 
та кількість упроваджених у виробництво нових технологічних процесів та фактор «інноваційний вихід», він пояснює 38.47\% загальної дисперсії та включає в себе показники: кількість упроваджених видів інноваційної продукції, обсяг реалізованої інноваційної продукції та кількість виданих патентів. Саме корегування та покращення даних факторів дозволить підвищити рівень ВВП на душу населення та покращити конкурентні позиції на світовому ринку, саме можливості такого прогнозування й буде предметом подальших досліджень.

\section{AUTHORS CONTRIBUTIONS}

Conceptualization: Viktoriia Tomakh.

Data curation: Hanna Veretennykova.

Formal Analysis: Viktoriia Tomakh.

Funding acquisition: Hanna Veretennykova.

Methodology: Viktoriia Tomakh.

Software: Viktoriia Tomakh.

Writing - original draft: Viktoriia Tomakh.

\section{СПИСОК ЛІТЕРАТУРИ}

1. Ahmadov, D. (2020). Stem effect on GDP in eu countries: Labor force perspective. Journal of Eastern European and Central Asian Research, 7(1), 114-121. https://doi.org/10.15549/jeecar.v7i1.236

2. Alheet, A., \& Hamdan, Y. (2020). Evaluating innovation-driven economic growth: a case of Jordan. Entrepreneurship and Sustainability, 7(3), 1790-1802. https://doi.org/10.9770/jesi.2020.7.3(23)

3. Archibugi, D., Filippetti, A., \& Frenz, M. (2013). The impact of the economic crisis on innovation: Evidence from Europe. Technological Forecasting \& Social Change, 80(7), 1247-1260. https://doi.org/10.1016/j.techfore.2013.05.005

4. European Commission (2020). European innovation scoreboard. Retrieved from https://ec.europa.eu/growth/industry/policy/ innovation/scoreboards_en

5. Global Innovation Index (2020). 2019 report. Retrieved from https://www.globalinnovationindex.org/gii-2019-report

6. Ivanilov, O., \& Syrom'jatnykova, Gh. (2013). Metodychnyi pidkhid shchodo kompleksnoho analizu innovatsiinoi diialnosti pidpryiemstva [Methodical approach to the complex analysis of innovative activity of the enterprise]. Ekonomichna stratehiia i perspektyvy rozvytku sfery torhivli ta posluh - Economic strategy and prospects for the development of trade and services, 1(2), 76-82. (In Ukraine). Retrieved from http://nbuv.gov.ua/UJRN/esprstp_2013_1\%282\%29_13

7. Kijek, T., \& Matras-Bolibok, A. (2019). The relationship between TFP and innovation performance: evidence from EU regions. Equilib-rium. Quarterly Journal of Economics and Economic Policy, 14(4), 695-709. http://doi.org/10.24136/eq.2019.032

8. Knoema (2020). Official web-site. Retrieved from https://knoema.com

9. Kraus, N. (2019). Innovatsiina ekonomika v hlobalizovanomu sviti: instytutsionalnyi bazys formuvannia ta traiektoriia rozvytku [Innovative economy in a globalized world: the institutional basis of formation and the trajectory of development] (492 p.). Kyjiv: Aghrar Media Ghrup. (In Ukraine). Retrieved from http://elibrary.kubg.edu.ua/id/eprint/26481/1/\%D0\%9C\%D0\%BE\%D0\%BD\%D0\%BE\%D0\%B3\%D1\%80\%D0 \%B0\%D1\%84i\%D1\%8F_\%D0\%9A\%D1\%80\%D0\%B0\%D1\%83\%D1\%81_\%D0\%9D..pdf

10. Kuzkin, Ye., Cherkashyna, T., Nebaba, N., \& Kuchmacz, B. (2019). Economic growth of the country and national intellectual capital (evidence from the post-socialist countries of the central and eastern Europe). Problems and Perspectives in Management, 17(1), 348-359. http://dx.doi.org/10.21511/ppm.17(1).2019.30

11. Liubkina, O., Murovana, T., Magomedova A., Siskos, E. \& Akimova, L. (2019). Financial Instruments of Stimulating Innovative Activities of Enterprises and Their Improvements. Marketing and Management of Innovations, 4, 336-352. (In Ukraine). http:// doi.org/10.21272/mmi.2019.4-26

12. Lomachynska, I., \& Podgorna, I. (2018). Innovation potential: impact on the national economy's competitiveness of the eu developed countries. Baltic Journal of Economic Studies, 4(1), 262-270. (In Ukraine). https://doi.org/10.30525/2256-0742/2018-4-1-262-270

13. National Science Foundation (2018). Science and Engineering Indicators 2018. Retrieved from https://www.nsf.gov/ statistics/2018/nsb20181/

14. Pece, A., Oros, O., \& Salisteanu, F. (2015). Innovation and economic growth: An empirical analysis for CEE countries. Procedia Economics and Finance, 26, 461-467. https://doi.org/10.1016/S2212-5671(15)00874-6

15. State Statistics Service of Ukraine (2020). Official web-site. Retrieved from http://www.ukrstat.gov.ua

16. Statistics Poland (2020). Official web-site. Retrieved from https://stat.gov.pl/en/

17. Vodianka, L., Pidhirna, V., \& Syroizhko, K. (2018). Foreign experience of state regulation of innovation activity. Investytsii: praktyka ta dosvid - Investments: practice and experience, 9, 77-82. (In Ukraine). Retrieved from http://www.investplan.com.ua/?op=1\&z=6074\&i=14 